\title{
Article
}

\section{Bandas beyond their 'Ethnographic Present' \\ Neoliberalism and the Possibility of Meaning in Mexico City}

\author{
Adina Radosh Sverdlin \\ Universidad Iberoamericana
}

\begin{abstract}
Mexico faced significant financial crises during the late seventies and early eighties emanating from the Mexico City, due to its centrality. These crises were connected to the introduction of neoliberal reforms in the country. Simultaneously, a form of children and youth organization appeared in some of the incipient and impoverished neighbourhoods in the West of the city, the bandas; parallel to the inception of 'City Santa Fe,' a luxurious utopia. Difficult urban and social conditions, violence and uncertainty not only gave birth to the bandas, but became their insignia. A temporal distance of nearly three decades from the birth of the bandas allows for a procedural analysis that overcomes the temptation to limit a research on youth groups to their 'ethnographic present.' The bandas' members narrate their life trajectories as search for better scenarios and, along the way, find meaning and order in otherwise chaotic events. Belonging to a banda serves as a coordinate from where to array a set of events and processes, and assess their outcomes, a coordinate for framing certain 'masculinity projects', allowing feelings of progression, satisfaction and even redemption.
\end{abstract}

Keywords Bandas, life trajectories, masculinity projects, neoliberalism, meaning

Mexico faced significant financial crises during the late seventies and early eighties, which led to the introduction of neoliberal reforms. In Western Mexico City, this coincided with the proliferation of a form of urban children and youth organization known as banda, and later on with the birth of the 'City Santa Fe' project, the setting for luxurious residences, big shopping centres and office buildings. The bandas became a much studied topic. They worried authorities as much as they intrigued academics and journalists. However, the analysis presented here differs from the earlier works; with the temporal distance of nearly three decades, it favours and offers a procedural perspective.

Let me first offer a general contextualization of the development of the area of study and an analysis of its physical characteristics. This will allow us to reflect upon the economic and social processes that enable certain political practices that extend throughout these neighbourhoods, relating them to discussions about political practices in Mexico at large. Consequently, we will discuss some of the life trajectories and 'masculinity projects' that were constructed among the bandas (Connell 2003). In doing so, we avoid the temptation to confine the research to the 'ethnographic present,' broadly found in gang and youth group research. Instead, we will investigate how individuals search for better material, educational and social conditions (alivianes) at the same time as certain local political mechanisms tend to perpetuate urban poverty, paving the way for local and extra-local actors to take advantage of this situation. Whereas bandas' members incarnate urban misery, it would be wrong to portray them as marginal subjects or outcasts; some have successfully entered local politics either through political 
parties, unions, and even clash groups ${ }^{4}$ or make their way into criminal networks. This methodological choice derives not from the author's wittiness (it would be too presumptuous to pretend that), but from the moment at which the interviewees stand today. It is this moment that insists on the complex interplay between past and present; the past is built in (and for) the present.

The research was conducted in several neighbourhoods located in the Delegación Álvaro Obregón and Delegación Miguel Hidalgo, in Western Mexico City. Formally, the fieldwork was conducted from August 2015 to February 2016; however, by that time, I had spent three years involved with an NGO and a religious centre performing different activities in the area. I was able to interview 18 members belonging to 7 bandas, searching to understand the formation and development of their groups and their life trajectories. In addition, I interviewed several locals that were not members of a banda but had important information regarding them. Also, I assisted in cultural, social and religious activities organized by banda members and was invited to walk around the area in order to get to know particular landmark spots to the bandas' development. All of the bandas members interviewed were male (I tried to include a female perspective, but could not manage to contact any woman that was involved with the bandas, although in my interviewees' narratives female figures appeared as banda members ${ }^{5}$ ) and aged omewhere between 45 and 60 .

\section{A Brief Contextualization}

'[We are the] children of the marginalized ones' stated Sapo, a member of Verdugos. Lack of public services, uneven and unpaved streets and unsafe constructions were common conditions in the Delegación 6 Álvaro Obregón and Delegación Miguel Hidalgo neighbourhoods from where the bandas originated. Harsh surroundings partly owed to the fact that a large portion of the territory was located in the Tacubaya and Becerra rivers' gullies, but also to the land exploitation carried out over decades in order to extract building materials that partly supported the construction and industrialization of greater Mexico City. The area saw a burst of unplanned and mostly self-constructed houses that shaped the new neighbourhoods. Even though these circumstances posed a significant danger for the populations, they also translated into stimulating and attractive spaces for kids and young people: abandoned mines, caves, gullies and rivers, and even the nearby belated rubbish dump (forever buried beneath luxurious buildings and a park) were excellent places for adventure, shelter from police, hanging out with friends and even finding time and space for intimate moments with partners.

The surroundings were heavily polluted (even more so today) due to the effects of the industry settled for many decades in the area, and later mass human settlement. The

\footnotetext{
4 Known in Mexico as either porros or grupo de choque, they are usually related to either university or governmental authorities, and exercise an illegitimate use of violence. They have been vastly used to repress and delegitimize social mobilization, but may pursue other political, social or economic interests.

${ }^{5}$ Recently I have met several women that belonged to different bandas, therefore their perspective could be addressed in future research.

${ }^{6}$ While the rest of the states in Mexico are divided into municipios (municipalities), Mexico City is divided into delegaciones. Throughout the article I will refer to the delegaciones also as municipalities.
} 


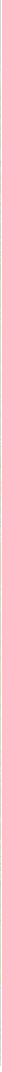

Fig. 1. Becerra River gully's streets with a football field, seen from the other side of the gully. A big office building can be seen on the far left. Image: author.

setting (as many others in Latin America) has been strongly polarized since the late eighties, as luxurious residences, universities, schools, office buildings and malls have developed oftentimes directly next to impoverished neighbourhoods. Not unlike urban spaces in other parts of the world, such as India (Kuldova 2017). Even though water, soil and air pollution know no income boundaries, and may trespass from one side to the other, there are some urban preconditions and political mechanisms that augment and focus the vulnerability on the impoverished populations more heavily than on others. In Butler's words, it magnifies their precarity (Butler 2009).

For instance, contaminated rivers are tubed as they pass through the upper class neighbourhoods in 'City Santa Fe', but then run freely as they pass alongside impoverished neighbourhoods. Precisely for this reason, some of the most vulnerable areas are those closest to the rivers, fundamentally to the Becerra River. Even more worrisome is that the few playgrounds, football fields and open air gyms in these areas tend to be on the banks of the rivers, as 'recovered spaces' fostered by governmental programs, local populations and NGOs, since the overcrowded area has no other space to develop such recreation facilities. These spaces have also become drug dealing and consuming spots as they are somewhat concealed and there is little police surveillance. Interviewees assert that the conditions that prevailed when they were growing up, 
combined with the overcrowding experienced inside their homes and parental absence due to work schedules, resulted in their expulsion to the streets, where they could gather with their peers.

'For us the streets are something symbolic, right? Because while for other young people or for other children the physical space was the park, right? Recreational spaces, spaces with better conditions, 'alivianados'7 for us... the streets. But our streets were the mines, the caves, right?' (Luis Guerrero, Verdugos)

According to Luis, being on the streets with peers gradually progressed into the creation of the bandas. Even though he admits that this process is not exclusive to this area, its specificity comes from the environment, with its caves and mines. But this specificity is also attributable to the presence of government buildings and schools in the area that later on linked the bandas with key actors and contributed to their local strength which, for some, translated into their positioning in governmental offices, ${ }^{8}$ government-related unions and public universities.

\section{The Industrial Footprint}

Let me take a step back and briefly narrate the industrial development of the area, since it is accountable for the settlement processes and proliferation of certain political devices. From the $19^{\text {th }}$ century until 1930, an agricultural exportation model prevailed in Mexico and then coexisted with an import substitution industrialization model, which influenced the centralization of the economy within Mexico City. Prioritizing Mexico City's industrialization to the detriment of peasant work outside of the city (obliged to produce cheap products to feed the workforce as well as to export at low prices), led to significant migration waves toward the capital in search of work opportunities. Even at the peak of the government-assisted industrialization process, the city could not employ all of the migrants, increasing the informal work sector. Moreover, these populations tended to settle in the margins of the city, expanding Mexico City's borders, especially between 1930 and 1970 (Gillingham and Smith 2014, Márquez López and Padilla Lobos 2008).

Wheat and paper mills were the first industries in the area, settling in Tacubaya (today Miguel Hidalgo Municipality) from the $16^{\text {th }}$ century; in the $18^{\text {th }}$ century a gunpowder factory relocated to the vicinity and the lands were exploited in order to obtain building materials. From the late $19^{\text {th }}$ century, more factories appeared mostly in the Álvaro Obregón Municipality, predominantly for construction materials (cement, asbestos, etc.). By the 80 s, the construction material industry had such a profound impact that $70 \%$ of the Álvaro Obregón Municipality found itself on mine zones and more than $40 \%$ of the land was considered highly dangerous for human settlement (Camarena Ocampo 2000).

\footnotetext{
${ }^{7}$ Alivianado in Spanish literally means 'lightened' but, in this context, it refers to having better conditions, being well-off.

${ }^{8}$ An interlocutor recently (after my fieldwork was over) suggested that the Álvaro Obregón Municipality is unlike others in Mexico City, partly due to the characteristics imprinted by former members of the bandas; he argued that some entered municipality offices through reintegration programs that offered them working opportunities.
} 


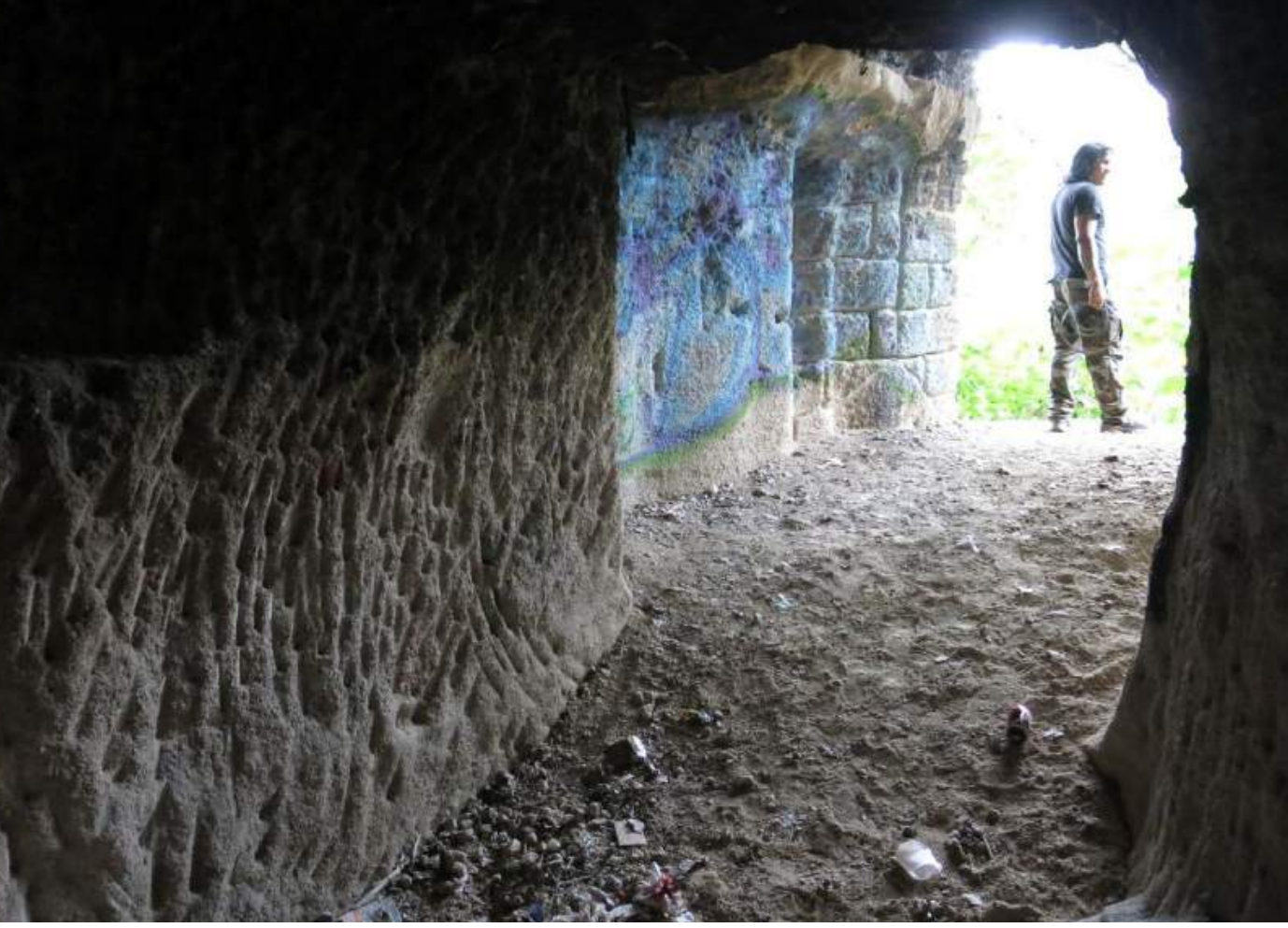

Fig. 2. An artificial cave created by the construction material industry, viewed from the inside. Image: author.

The import substitution industrialization model ceded by early $80 \mathrm{~s}$ as a series of financial crises hit Mexico (and mainly Mexico City), starting in the late 70s. In Álvaro Obregón, from 70 s to early $80 \mathrm{~s}$, a significant number of factories closed their doors, some of them relocating to other states in accordance with a decentralization effort. The industry moved northwards, both within Mexico City, and to northern states, aiming to export to the U.S. and supply big cities like Monterrey and Guadalajara (Cruz and Garza, 2014). Evidently, we cannot speak of a deindustrialization of the country as such, but of certain areas. These deindustrialization processes promoted a polarized tertiarization of the industry, in both the formal and informal sectors (Márquez López and Padilla Lobos, 2008).

Simultaneously to the closing of the factories, and not unrelated, the 'City Santa Fe' project emerged near the rubbish dump. The Universidad Iberoamericana, a private university, where I studied, was relocated to the area in 1983, unveiling the titanic project: one that seemed to give its parting wishes to the worn-out industrial Mexico City and open itself to a new era of transnational enterprises and enormous mirror covered buildings. During the 80s, taking advantage of the country's crises, the International Monetary Fund and the World Bank encouraged/coerced or else 'throffered' (threat/offer) the introduction of neoliberal reforms that would open the 
market and privatize services, among other measures. In Mexico, as in other Latin American countries, from the 40 s to the 60 s, government workers and organized labour achieved a certain amount of social security and workplace related comradeship that also translated into sports, religious and family events.

When they first came into being, most of the neighbourhoods in the area lacked proper infrastructure; the only exceptions being those connected to certain factories, whose workers experienced the above referred social welfare and individual and familial belonging strengthen through sport teams, music bands, civic and religious festivities and adoration of a holy patron. This set a precedent for aspirations that much of the population never achieved; political practices learnt from unions spread and were used in adjacent neighbourhoods. Perhaps certain strategies of belonging observed among the bandas are distorted remnants of the once glorified working class identity, only this time revolving around the streets rather than the workplace.

\section{Political Practices}

Living under difficult economic and social conditions forced the population to organize locally and to pressure municipal authorities to meet their needs. This allowed a permanent link that at times translated into political support and cooperation through corporatist mechanisms, but also resulted in violent confrontations, as when the municipality tried to evict people that lacked the proper land ownership documents. As early as the 30s, Mexico City saw 'invasion-expropriation-regularization' processes of land linked to housing insufficiency (Ortiz Madariaga 2015). By the 60s, the authorities tolerated (or even encouraged) the informal occupation of land which, in turn, intensified the migration waves into the city (Davis 1994, Rojas Quincosa 2015). The 60 s also saw an increase in local organization in the city, whose demands included access to urban services and land regularization.

Accordingly, in the research area, poor neighbourhoods with no links to factories or unions had a greater need to create pressure mechanisms in order to demand services and resolve their problems and shortages (Yáñez Reyes, 2003). Undeniably, this led to the constant re-creation of the link between authorities and populations, but also to the appearance of local leadership that have been studied in Mexican political literature as either intermediaries, brokers or caciques (for a thorough examination of the cacique role in $20^{\text {th }}$ century Mexican politics, see Knight and Pansters 2006).

Mexico City and the State of Mexico were the cornerstone of the Partido Revolucionario Institucional (PRI, Institutional Revolutionary Party), which ruled the country for 71 years (from 1929 until 2000); its corporatist practices rested partly on its linkages to organized labour and capital, and relied to some extent on class identifications. However, the population growth, the lack of services and infrastructure (mostly in low income neighbourhoods but also among the middle classes) and the limited mechanisms through which urban needs could be channelled to the authorities fostered increasing dissatisfaction with the PRI in the city (Davis 1994). The PRI's support decreased in the $60 \mathrm{~s}$, but more so during the $70 \mathrm{~s}^{9}$ and reached strikingly low levels in the $80 \mathrm{~s}$, after the

${ }^{9}$ After the 1968 student protest that ended with strong repression and the killing of civilians. 


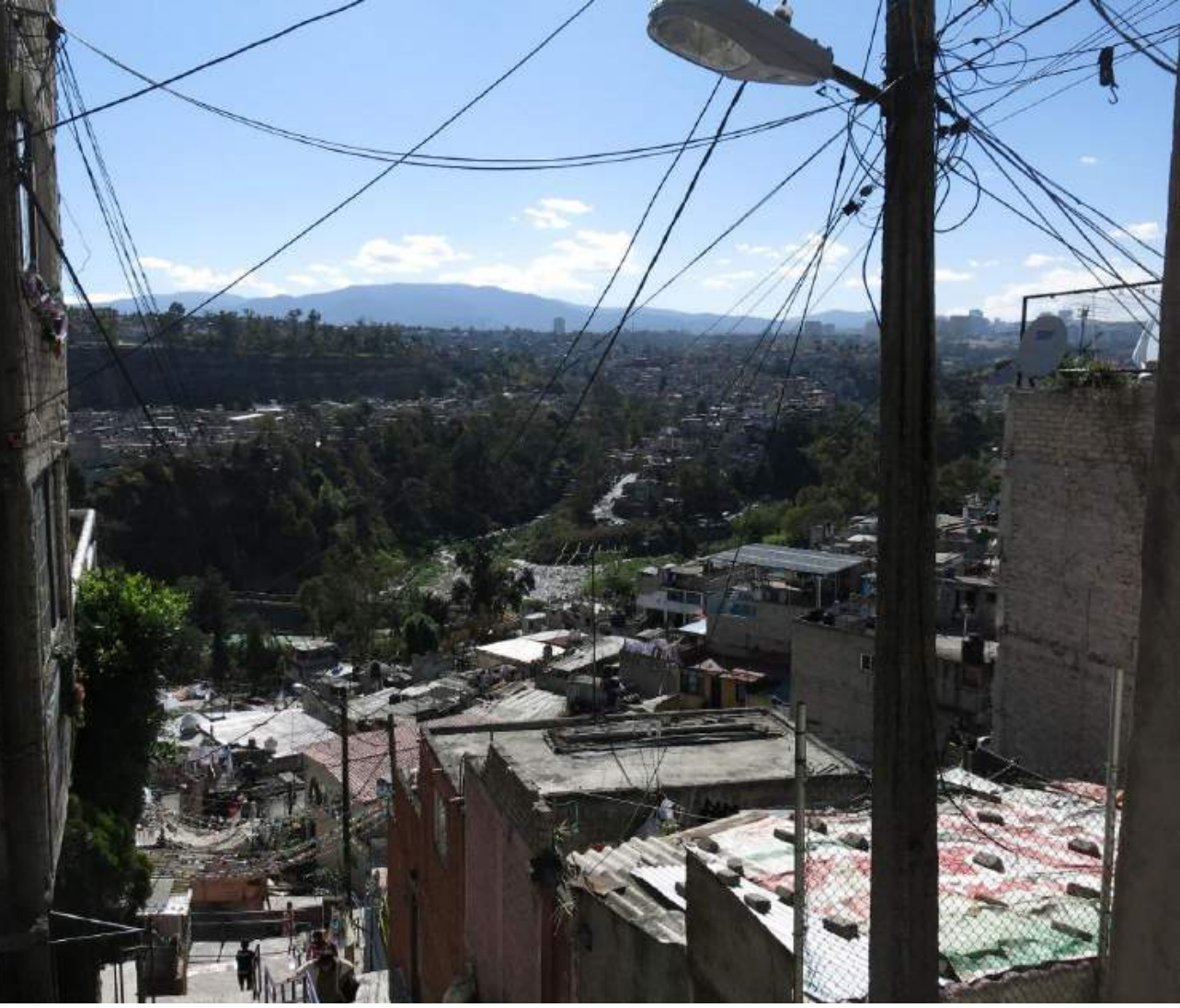

Fig. 3. The view from an ascendant alley: the Becerra River, some neighbourhoods on the other side of the gully and City Santa Fe on the far right. Image: author.

fiscal crises hit the city and then expanded to a national level. ${ }^{10}$ Corporatism became more difficult as urban demands brought urban populations and social movements closer, as it alienated them from the party's institutional mechanisms (Davis 1994). However, the PRI plays a central role in party politics to this day; Mexico's current president, Enrique Peña Nieto, comes from a priista (that is, related to the PRI) lineage: the Atlacomulco Group (based in the State of Mexico).

During the 80s, when neoliberal reforms took place, urban services and industries were privatized, the industry underwent a certain decentralization, and the government implemented tough austerity measures in the city. By 1985, urban services in Mexico City worsened and crime increased (Harvey 2005). The outrage felt by much of the population paved the way for the birth of the Partido de la Revolución Democrática (PRD, Party of the Democratic Revolution), created by former PRI members. The PRD succeeded in the incorporation of different organizations and achieved significant support in Mexico City since its program aligned with local demands and dissatisfactions

\footnotetext{
${ }^{10}$ Also due to a deficient response from the authorities during the ' 85 earthquake, as contrasted with the reaction from civil society and individuals.
} 
(Davis 1994). It is not surprising then that some of the bandas' members joined the PRD and even became its local representatives.

Either through the PRD or otherwise, some people from different bandas currently work or have done so in the administration offices of the municipalities (both Miguel Hidalgo and Álvaro Obregón), as well as in other government offices. This is not necessarily the case in other spaces, or in other municipalities in the city. This exposes the local strength of the bandas and their not-so-marginal state; some of its members can now claim access and know-how of political procedures, though certainly not all of them.

\section{The Search for Alivianes as an Active Process}

Julio was born in 1956 in Tacubaya, but then moved with his family to a neighbourhood in Santa Fe. When they arrived the area was getting populated, only the main avenue was paved and a few plots were connected to the water system. He remembers that on the other side of Santa $\mathrm{Fe}$ (now the wealthy side) only mines and dumpsters were to be seen. The first floor of his house was built with bricks made out of materials found on the surroundings by his own family.

Julio belonged to the Golfos and Pantanos bandas; both were related to the Panchitos, but also to small-scale drug dealers. He himself sold drugs and eventually got caught by the police in 1987 and spent seven years in jail. While imprisoned, he met several high-rank drug dealers that guaranteed a good drug supply, hence he continued to sell. He got caught three times for selling drugs in prison, but was never sentenced by it; 'it's just like here, outside, if you pay they let you work.' He claims to have had a good relation with both the guards and inmates due to his chores, but also for his religious inclinations.

'I was looking for God, looking for God in many ways, I started to know him in jail. As the people in jail already knew me as a drug dealer, but also close to religion, but in a traditionalist way, so that, well, I hadn't learned well about God, [...] we all hold on to God to our own convenience, right? And, the boys came to me to pray the rosaries for their dead people, right?'

Looking back, Julio points to tough experiences that he attributes to drug abuse; such as being shot on the leg and thereafter spending 13 years walking with crutches, and losing a finger while doing carpentry. He recalls that quitting drugs was an unequivocal action for him, already being on the outside (of jail) when his kids were old enough 'to realize.' When released, he approached a priest who recommended some Bible lectures, but he did not find them appealing. Subsequently, he met a group of nuns that lived and worked near his house, who preached Liberation Theology.

'And when I was out I started to look for God in churches, in the parishes, until the moment that some people taught me [...] Jesus Christ's practices through Liberation Theology, that I liked very much, and that is how I started, well, to find God through men, through service, not just being shut in in a temple and beating myself in the chest, right? Without acknowledging others.' 
It was with them that he learnt that God is in the actions and not in contemplation. It was also through them that he was sent to the US to have his leg treated (and healed), after some doctors had already condemned it to amputation as it showed signs of gangrene. Working with the nuns, they established a kindergarten to assist single mothers and particularly those who struggled with addiction. They managed to get old clothes, shoes, books and toys as donations from local churches. Likewise, they received furniture from a charitable foundation, supplies from companies, and courses by the Universidad Iberoamericana (a Jesuit university). After some years in operations, Julio decided to leave the project resulting from internal disagreements. However, he reengaged with the nuns to work in 'addiction damage reduction' actions. Under the same line of work, he joined a Jesuit priest known as 'padre Banda', after his closeness to 'banda boys'. With time, he has taken various courses and certifications about drugdependency to complement his experiential knowledge.

Assessing his life, and considering different stages, he concludes that it was all needed for him to have the proper tools to work with people struggling with addictions and those related to criminal networks:

'When you learn about the Bible, you realize that all of the people that are inside [of it] first had to live their reality in their community to be able to announce and denounce, right? [...] you realize that God sets for us the path of love, the path of science, the path of faith, and the path of reality. Some [go] through the path of science, some go through the path of faith and others through reality, right?'

Julio has assembled football teams with young addicts to make sure that, at least for a few hours, they will not consume and instead enjoy a physical activity they like. He constantly visits prisons, rehabilitations centres and walks the streets to make a presence so people can approach him if they want help dealing with an addiction or just want to talk to someone. He also works at a parish making repair and carpentry work, and regularly attends dance halls, as he is deeply passionate about dancing.

'When people [in Santa Fe] saw me, when I was on drugs, well, they saw me with dread, with fear, "so there goes that addict, drug addict:" that's the way they call us, "mariguano", whatever you want, right? So today, I go by with my forehead high and the same people tell me: "Well Julio... what a turn have you given! Really, what a turn have you given, a hundred and eighty-degree turn because, from what you used to be, now you don't even have a ten percent, right? Now I congratulate you on working for the parish, working for the people in our community, now you devote yourself to being the doctor of the boys, through the experience you have."

\section{Youth}

Although it may sound somewhat predictable, for the interviewed banda members, youth is considered as a time in life meant to experiment, have extreme bodily experiences, and to challenge parental, police or school authorities. Many attribute at least some of their practices both to their youth and the use of drugs. Youth, more than a strictly 
determined age group, is constructed by a series of attitudes and actions; some of the banda members were as young as 8 or 9 years old when they started partaking in them.

This construction of youth aligned with the introduction of rock as youth music, even if some bandas and individuals preferred other music genres, there is a clear connection between bandas and rock, specifically urban rock (and later punk and hard-core). The consumption of alcohol and drugs as means of experimentation and enjoyment, and the production of violence as a way to earn respect and relate to others marked their practices, denoting an environment of hedonism and presentism. The place and time when music, alcohol, drugs, gathering, confrontation and even flirtation converged was in the tocadas, events where different local or extra-local bands play, usually on the streets in the organizer's neighbourhood, but sometimes in bigger institutional or commercial establishments. Attending the tocadas allowed incursions into new territories which, in turn, established alliances with other bandas or created the perfect setting for massive collisions, sometimes topped by police disruption.

In this respect, bandas and police forces had an ambivalent relationship; usually characterized by open confrontation, but at certain times the police approached the bandas trying to add them to their ranks, as a way to make use of their violence and exploit the situation of limited employment and educational opportunities. These attempts were unsuccessful in the area of this study, but apparently prospered in other municipalities. Police forces and the media depicted banda members as delinquents and addicts, this in turn led to their constant chase by the police. Sometimes they were apprehended just for 'looking like chicos banda' (banda boys). The results of such apprehensions included police practices such as torture and extortion of the bandas' families.

The familiar triad youth-violence-masculinity arises. Abarca and Sepúlveda discuss along similar lines football followers in Chile, where creation of masculine identities is related to territorial domain and violence (Abarca and Sepúlveda 2005). Similarly, Jorge Quintero, a member of the Salvajes refers to the 'power of the barrio' (hood) and is certain that the growth and strength achieved by the bandas are because of this particular power:

'When we started to gain fame, a shitload of assholes started to look for us [...]; "what's up, we want to mess around with you" and that is how the power started; more and more power. To draw more power from all of the hoods around, they started to gather here, here in the Cuernito. [...] The fame we started to create made a lot of bandas want to join us. [...] But first they had to go through a beating, dude, it wasn't that they would show up and fine; no, no fucking way. They had to go through the entire banda, through a beating, we gave them some hitting. If they held up the beating: "dude, ok, you are part of the banda."

[He indicates that part of their power came from activities like robbing people on buses, even raping women; though he hurries to explain that he never agreed on the latter.] 
So, as I tell you, the power began to emerge thanks to the power of the hoods, for having... for wanting to feel tough [...]. There were struggles of a hood against another, whoever dies, dies.' (Jorge Quintero, Salvajes)

This power of the hood rests upon gaining a reputation for being violent, inspiring fear and respect among other bandas and making clear that entering their territory would be a dangerous endeavour. On the other hand, it relied on creating a desire among local people to join them as a way to gain respect and tactical capabilities. Another member of the same banda, after participating in an Alcoholics Anonymous group, explains this search for power as follows:

'Now I know that we were sons of plumbers... it was a lower sociocultural extract, and that's why we were more aggressive. They used to say: "don't go through the Cuernito, dude, because they rob your tennis shoes, they take your jacket, they beat you." Because it was a way of freeing ourselves, to make us look meaner, right?' (Nicho, Salvajes)

It should be clarified here that the Salvajes, as well as the Panchitos, managed to create an image of particularly violent bandas; whereas the Verdugos favoured an image of social struggle, activism or social movement. ${ }^{11}$ Nicho's claim resembles Cohen's theories: belonging to a gang serves as a mean to reconstruct one's self-esteem after it has been eroded by middle class expectations that collide with low class settings and conditions, relying on working class virility and dignity (Cohen 1965).

Connell on the other hand claims that among the working class, the body is not only an 'economic asset' but also a core element for the definition of masculinity; but when working class identification processes are no longer available, masculinity does not confine itself to the working place, but instead oscillates in a back and forth process between employment and unemployment (Connell 2003). In this context, violence and belonging to a peer group gain utmost significance. Connell refers to this as the 'masculine protest', which objects to their structurally weak conditions and tries to resolve the contradiction in which they find themselves (being underpowered males in a patriarchy) by displaying a violent facade (Connell 2003). However, the 'masculine protest' does not resolve the contradiction and even works to the person's own detriment. Rudeness and respect building, besides materializing through territorial defence, is reflected physically on bodies, attitudes and attires. Being strong and prompt was needed to confront others, and displaying a coherent outfit helped achieve this ruthless image. While the gathering of tens could achieve an intimidating effect; intimidation was also embodied in the leaders themselves.

'Without wanting to praise him, but he is someone of high level and respect for me. I mean, I don't want to talk bad, $[\ldots]$ or praise him as

\footnotetext{
${ }^{11}$ This image was strongly supported by the creation of the Consejo Popular Juvenil (Popular Youth Board), attributed mainly to the Verdugos, although most of the other bands, at one time or another, collaborated with them.
} 
a God, but... [...] he is feared inside [jail] and outside. [...] Outside, when we met him as a kid [...] he moved others because of his height and he was skinny, not like now. He was skinny but well built. He wore jeans and Converse [shoes] and a denim or corduroy jacket. And corduroy pants and his little hats, right? [...] He was handsome, that mother fucker. He was handsome.

$[\ldots]$

What he used to tell us, what he ordered us to do we had to do because otherwise, the following day, he would see us and hurt us or even kill us or let us die for disobeying him. That was his law for us; we were young.' (Anonymous)

In this context, there are some concepts that are used to describe the respect and admiration inflicted by the bandas with shades of gender constructions: 'ser chingones' (being badass, cool and/or great), 'huevudos' or 'de huevos' (having a lot of balls):

'Even... I will tell you one thing, it used to be very tough; if you didn't act badass (si no te ponías verga), they'd kill you. [...] It was really tough. So the power of the bandas was gained through having balls (huevos). And also the multitudes, the multitudes; we used to be a shitload.' (Jorge Quintero, Salvajes).

It is important to point out, with no intention to offer a semantic analysis, that 'verga' is a slang word for penis and 'huevos,' as said before, for testicles. They are linked to aggressiveness and courage. Also, this set of rude attitudes is somehow connected to being urban, seeing rural boys as less brave, less articulated when engaging girls, less stylish, more self-conscious, close-minded and even repressed. Even though banda members would have a family in the countryside or in other cities, they actively tried to erase any hint of rurality or traditionalism. Despite the fact that the chavo banda (banda boy) personifies urban misery, he is still urban and therefore, superior to his rural counterparts.

\section{Body}

The body becomes central for experimentation, violence and encountering others in this context. Focusing on it, and allowing myself a brief reflective interlude, I would like to turn to Butler's deliberation about precariousness and precarity (Butler 2009). Precariousness is the vulnerability common to all bodies and what gives way to our contact with others. Precarity is the magnification and focalisation of this vulnerability on certain populations or groups. Both are necessarily corporeal. Both emerge in my interlocutors' accounts: the possibility for the bodies to confront, collide, and feel, while simultaneously manifesting and incorporating (giving body) the wretched conditions observed in the physical space that surrounded them and in the limited educational and employment possibilities offered to them during times of deep financial crises. For the bandas, the body was used as a means to intimidate, communicate and confront. Oneon-one fights as much as 'pitched battles' demanded physical strength, tactics, and body contact, unlike the use of fire weapons that allow for an attack from a considerable distance. Also, alcohol and drug consumption, as well as listening to music or dancing, 
are all intensively sensorial experiences. The tocada is the paramount moment for the confluence of bodies and the manifestation of intensities.

Nevertheless, due to my Spinozist inclinations, I will offer a somehow vitalist lens. ${ }^{12}$ Not as to erase or diminish the weight of violence and injustice, but to understand the way people seek relief and better conditions, what my interlocutors define as 'aliviane.' Being as complex and contradictory as it is, sometimes these alivianes may end up adding more violence and suffering for themselves or others. I will attempt to connect the alivianes with Connell's outline for a study of 'masculinity projects', but first, let me devote some lines to a different subject.

\section{Establishing the Limits}

An issue that sometimes arose in the conversations I held with my interlocutors was rape. It was an uneasy matter, even to a greater extent than talking about murder. Perhaps because I am a woman, but also for its great moral burden. Possibly some masculinities can be negatively affected by admitting to having participated in a rape; an example of such repercussions is when someone is incarcerated for rape charges - he would get raped as a 'welcome', so that the offender receives as a punishment from the other prisoners precisely the same treatment that landed him in prison. Every man that mentioned this subject clarified that he did not do it, they were mere witnesses to other's actions. Only one person, eventually, admitted his own participation:

'I will look bad and everything, or, well, I haven't talked much about it, there the other time, well, I did not participate because I felt bad and everything, but I did watch how they raped a girl and her partner. Well, I did participate with that dude: I stole his money, I took the clothes I liked, [...] I beat him until I got tired. [...] You know, right? Having the devil inside and the drugs. [...] And yes, the girl, she was crying, traumatized, all beaten up, teared up, asking from us to pity her because she stayed there with her partner all beaten up, nude, I don't know, I felt panicky, but inside of me I was having fun as a psycho.

[Later on he adds] The truth is that we brought them [the girls] here and we raped them, from [another banda's] tocada. We left them stacked up and we left to continue messing around and who knows what they did or what the fuck. That easy. I mean, that was the deal a while ago. And now no, now you think over and over before you do stupid things, even to kill an asshole or hurt him, hitting a woman [...] or raping a girl: you think it once and a thousand times, right? Even if it is in a solitary place and all that shit, even if you get her high and that. You think it once and a thousand times more. No, back in those

\footnotetext{
12 Spinoza's conatus is a vitalistic drive: the power performed in order to preserve oneself and it is undeniably relational (Deleuze 2001). Spinoza differentiates between affection (bodily) and affect (of the soul) and they can be either beneficial or detrimental to one's conatus, depending on the outcome of the confronting powers (Spinoza 1958). Affects cannot exist without a body and bodies cannot exist without affects, as it is the way we relate to others, get to know and preserve ourselves (Spinoza 1958; Deleuze 2014).
} 
days even if she was dead I think we would have raped her and no big deal. No, I mean, we had no compassion, we didn't feel... We were cold blooded, we were cruel.' (Anonymous)

As the conversation flows, we get to a point where this person has switched from a violent and even bragging tone to one weighed down with regret: 'I acted wrong, may God forgive me'. The conversation fluctuated from moments of sincere repentance, verging on a confession, and others used as a way to manifest his great deeds and fearlessness, much needed in his hood and way of living. But still, at the end, he feels he paid for all of his wrongdoings; he spent time in jail and some convalescent months after an injury. His imprisonment and bodily suffering may be seen as legal and extra-legal (perhaps even divine) justice. Addressing this issue points, first, to the ethical limits that the bandas members draw around their actions in their violent and rebellious youth. On the other hand, it suggests that, in spite of having participated in violent and even shameful activities, going through specific processes (be it imprisonment, physical injuries or others, as we shall see) opens up the possibility of rectifying one's path or feeling that all of the wrongdoings were paid for.

\section{Cabrones or Well-behaved, but Never Putos}

One time, during fieldwork, I was with two interlocutors, Fido and Cholo, it was getting late, and I pointed out that I would leave soon. Fido assured me that they would walk me to the bus stop (as always), and Cholo went as far as to offer to accompany home. After they joked about how they would not be allowed into my house, Cholo added with a serious voice: 'so you see that with us you are with the banda, the machines'. Here, the term 'machines' alludes to their strength and respectfulness, as well as to their caring facet. 'Machines' has a positive connotation, even though it derives from macho, which is considered to be a negative characteristic. I faced this attitude throughout my fieldwork, as my interlocutors protected me not only thanks to their social and cultural capital, but also due to the working of gender relations (Gutmann 2000, Abarca y Sepúlveda 2005). 'Machines' are men that helped me with my research and accompanied me, but also who cared for me, being a woman almost twenty years younger than them and from a radically different social background. Gutmann highlights the fact that the men with whom he worked (in a popular neighbourhood) devote considerable time and energy to household activities and caring for their children; problematizing the idea that Mexican men are (only) machos (Gutmann 2000). However varied and fluid these facets of 'being a man' among my interlocutors may be, there is still a clear line drawn in respect to what type of masculinity is unthinkable:

'Over there [in jail], as they say, you have three options: either you come out cabrón [badass], the second one, you behave and stay out of trouble or the third one, you became puto [pejorative for homosexual].' (Pinacate, Salvajes)

My interlocutors would position themselves either as cabrones or well-behaved, often switching between them; avoiding being seen as putos at all costs. Likewise, as shown before, avoiding being seen as rapists; or at least avoiding showing themselves as such to me. Future works could enquire if there is a relation between the categories of 'rapist' 
and 'puto', the most visible one could be the threat of becoming puto (being raped) in jail if one raped outside of it.

\section{Looking Back...}

No longer considering themselves young, as they are between 40 and 60 years old, banda members still enjoy some practices that date back to their youth; however, inappropriately youthful behaviour is looked down upon. Banda members may indulge in dancing, drinking and partying during the weekends but, usually, they are aware they have domestic and/or occupational responsibilities. Nowadays, members of the bandas that still gather in tocadas and identify themselves as rockers or punks disdain those who, throughout the years, have joined the banda scene but were not 'original' members of a certain banda, those who did not get involved in the violence, those who did not suffer the consequences and who cannot display their past participation in certain activities. This can be manifested when pursuing recognition and legitimation mechanisms. Comparing today's youth from their neighbourhoods to their own, banda members find some considerable differences. One such difference is the current easy access to guns; in the past guns were difficult to obtain, and the violence was mostly performed with bare hands, sticks or rocks, sometimes even with Molotov bombs. Or things like today's lack of respect on the streets, the arbitrariness of violence, the worsening of the drugs' quality and its proliferation, the loss of values and the superficial and money oriented youth are common differences acknowledged among the interviewed.

Perea Restrepo argues that contemporary gang members distance themselves from previous 'historical will-driven' actors, and increasingly incarnate the 'market cultural project' subject: they are individualistic, pleasure-oriented, with no responsibilities, detached from the adult world, and responding to desire rather than reason (Perea Restrepo 2007). Although my interviewees would surely agree that today's youth falls into this category, most of the characteristics apply to their youth as well. I suggest we look at the bandas as a transitional moment towards this incarnation of the 'market cultural project,' but also evaluate it considering the passing of time and the nostalgia for banda members' gone youth. Even though it was not the case for most of the bandas, there was an attempt to generate an identity in the chavo banda (the banda boy) as the foundation for a social movement, and a means of returning to the 'historical will-driven actors.' This project achieved a limited centralization of the bandas in the area and there are still some remnants of its identity building and the creation of cultural activities, such as organizing tocadas with altruistic purposes, artistic workshops or sports tournaments.

\section{The Possibility of Meaning}

Stressing the argument that being part of a banda is strongly linked to the creation of 'masculinity projects' and life trajectory narratives, and understanding them as constant processes and projects, necessarily implies that they are not coherent, monolithic, or stable. Although the time when the bandas emerged seemed to be a moment of uncertainty, and many would argue that this instability has stretched and even worsened as the years went by, my interlocutors offer linear and progressive narratives. Being part of a banda offers meaning, a logical progression, satisfaction and even a sort of redemption. This, of course, presents itself with different intensities for different individuals. 
lead to disputes in the household, especially when the partner/spouse does not share the same music and entertainment preferences.

Spiritual trajectories (like Julio's narrative, presented above) not only promise redemption, but also a radical resignification and functionalization of the banda past; according to some members, without having participated in a banda they would have never arrived at their spiritual path. In Julio's case, linked to Liberation Theology, the past is considered to be part of the very preparation the person needed in order to obtain knowledge and capacities to work with drug addicts and incarcerated individuals, finding God in other people. Alcoholics Anonymous presents a similar approach, as manifested in the case of another informant. For two other cases, related to a Pentecostal and Mormon Church respectively, the banda past and consequent conversion turns into a majestic example of God's existence and power, which is shared through testimony. Also, in these two cases, the conversion serves as a rebirth, a start from scratch, but one that does not forget the past. The spiritual path becomes a strategy for coping with one's wrongdoings and recasting them as having been necessary for getting to where one is now. The domestication of men described above takes new dimensions in the spiritual trajectories, as these demand one leaves behind certain practices, such as substance consumption and even some entertainment activities that take place on the streets; as is also the case elsewhere, e.g. for Wolseth (2011) in his research with Honduran gangs or Pfeiffer, Gimbel-Sherr and Augusto's research (2007) on conversion practices in Mozambique.

Conversely, in respect to the social struggle and political path, the scenario is less inspiring; although those banda members who have achieved political success may live under better conditions, they often feel a huge amount of disillusionment for not achieving what they set out to, for not being able to bring better conditions to their surroundings or observing an active, educated and promising youth today. The figure of the social struggler almost seems outdated, a vestige of an era prior to the incarnation of the 'market cultural project.' The sense of disillusionment can be partly palliated through the organization of cultural, sports or social activities. Throughout my research, this was manifested in carrying out tocadas inside jails as a way to bring music and entertainment to old fellow banda members that are still locked up, tocadas accompanied by mastography and prostate cancer detection services or the recollection of donations for the needy. Although alcohol and drugs are still consumed by bandas members, and even a few are still involved in low-scale drug dealing and other criminal activities; some tocadas are intended to offer 'healthy' entertainment sending a message of no drug and no violence during the events.

The banda sense of belonging and sharing a common past becomes a central issue in the tocadas; where the banda members yearn for their youth. There is a revitalization of the bandas, sometimes attached to a dispute for carrying the name of the banda as a banner, with a concern in telling their story and highlighting their membership to the banda and their experiences with them. This situation is related to their present moment in life and their pursuit of transcendence:

'What does a man want? He wants to be immortal; stay in the history in a book... that in the year 5,000 people will come and see what 
happened here in Mexico; that they will say "those Panchitos were cabrones [badass]"' (Fido, Salvajes)

Aside from their possibilities to transcend through their offspring or occupation, they have a great opportunity to do so in relation to their histories and past; they are the survivors, they are the reformed, they are the complex characters sometimes defamed and sometimes glorified. They want to tell their story and be heard. It is no coincidence that simultaneously to my research, there were two documentaries being filmed about the most (in)famous banda in the area (and the city): the Panchitos.

Being part of a banda, while not the only way, has given its members a core element in their life narrative - a pivotal point from where to topographically arrange different events and processes that have happened throughout their lives. These narratives imply mechanisms of belonging; taking some of their practices from working class or urbanpopular neighbourhoods that needed to be strongly organized and active in order to attain basic urban infrastructure and services.

We should look more closely into affect to further introduce profound, bodily and chaotic experiences into a discussion about politics. Neoliberalism is not only an economic, political and cultural project, but also an affective and sensorial one. With neoliberalism and the supposed end of the paternalistic phase of the state and of its clientelistic practices, citizens must step forth and enter a model of co-responsabilization. Organized society, and even the unorganized one, takes some responsibilities and activities previously adjudicated to the state. But what we often neglect in this account is that the co-responsabilization of citizenship opens up a broad spectrum of affect and meaning. That is, it sets an affective horizon where we can locate ourselves. We could speak about affects as ubiquitous flows and intensities that then crystallise into social relations, narratives and institutions. But these crystallizations concede the creation (or rather, reconfiguration) of affects. In consonance with this understanding, we can observe the state not only as a rational apparatus, but also as an affective and even visceral one (Laszczkowski and Reeves 2015). So, at this point, how far from each other are the most intimate and intense experiences my interlocutors have gone through and the political mechanisms of, let's say, the municipalities? Nonetheless, a succinct note should be made here: under no circumstances am I implying that 'politicians' (or 'businessmen') plan and perform Machiavellian orchestrations that perfectly designed and programmed the bandas. It is far more complex than that. It is a combination of the pre-political and the political; the irrational and rational; the chaotic and the planned.

The disappearance of factories, internal migration, limited job and educational opportunities and decadent conditions that were offered to banda members closed down important possibilities of meaning; but being part of a banda, and through it even refunctionalising those lacks, enabled other meanings and with them certain affects. The aesthetic, vitalistic and affective do not overshadow the political; they are interrelated. What kind of political practices are we talking about? Maybe not identitarian ones based on a project; maybe ones that while complying with 'official' politics, through bureaucratic and quotidian practices, legal and extra-legal mechanisms, generate affects in activities such as the tocadas and narratives that deliver meaning to our lives. As Adler Hellman has shown, compliance is not limited to imposed top-down mechanisms, as it 

But this has changed with time: maybe banda members still do not hold great expectations for the future (of the new generations' or their own), but their past is full with meaning, and personal narratives are linearly and progressively organized. They express, surprisingly, the previously uncared for sense of fulfilment. Still, some have informal and unstable jobs, and others are still fighting with addiction and its health, social and family consequences, others remain involved with low-profile drug trafficking and criminal activities. What we observe in this case is how under a neoliberal frame, having belonged to a banda and going through specific experiences, results in a starting point from where to make sense of one's life, to order all the otherwise chaotic and meaningless events. This is not to praise neoliberalism and forget (or erase) some of its disastrous effects; but to observe its facet as a paradoxical producer of meaning and expectations in a world of harm. Its most affective and intimate side.

Whereas neoliberal construction of expectation and the responsibilization of the individual may lead to the potentialization of uncertainty and anxiety, it seems that having been part of a socialization process such as the banda opens a possibility for signification and a feeling of progress, retroactively constructed, and, possibly, even a coping mechanism. These processes, in part, serve as ways to deal with and assimilate violent, guilty and even shameful incidents. Sometimes, interviewees express a sense of having paid back for what they did when they met with unfortunate events; this allows one to be at ease with one's wrongdoings. It favours an accomplishment route gained mainly through individual responsibilization, but with a degree of social commitment. This is even more evident when a spiritual process is undertaken (related to either a church or faith, or accompanied by an organization like AA); as acknowledging one's responsibility is fundamental.

The individual accomplishment can be obtained by the search for alivianes, which can be seen as having better conditions, being able to surpass an addiction or even consuming substances that momentarily help forget responsibilities and concerns. I like to see the alivianes as a vitalistic mechanism that helps overcome unwanted situations, even though they can have disastrous outcomes. Alivianes need to be evaluated in comparison to a prior moment; some banda members assess that, currently, they are in a better situation than when they were young realizing that, although their parents may have struggled to supply them with footwear and clothes, they are currently in a position to choose from a variety of designs. Accessing the consumption economy and the supposed freedom of choice can be of importance when evaluating one's trajectory.

These affective and aesthetic experiences do not exclude party politics and other political mechanisms. Neoliberalism is seen as an ever individualizing process, but it also gives way to new forms of socialization. We can find this socialization in the tocadas, but also in the organization of charity events or devoting oneself to others, which works perfectly with the co-responsabilization expected by different policies in varied areas such as security, education, health, and so on. Aside from the government's sharing (or avoiding) some of its previous responsibilities, citizens, may altruistically feel as though they are truly helping solve severe and structural problems by 'doing one's bit' and feeling good about themselves. Sometimes, these actions may even take place on the government's doorstep, as in the case of a tocada organized by bandas members (and other people) in order to collect clothes and goods for the needy, which took place in the 
municipal administration's facilities and with its blessing (permits). So, where do party and formal politics end and aesthetic, visceral and affective experiences begin?

We may say that the experiences of the bandas' members are 'extreme' ones, as we evaluate their violent behaviours or their radical change. But this may insinuate that they are marginal, which I think would be a misconception. In that respect, they move away from the violent, erratic but mostly powerless behaviour which Bourgois (1995) describes among the Puerto Rican youth in the Harlem or the 'mute protest' depicted by Perea Restrepo (2007); as they gain local strength, some of them have access and knowhow of political procedures. Shoshan (2008) scrutinizes the concept of 'extreme right' in Germany and asserts that tagging it as extreme helps to see it from afar, to detach oneself from those nasty behaviours, negating or trying to invisibilize the 'centre's' (our) own hatred, intolerance and xenophobia. We could think about the bandas in a similar manner: even though we tend to cast them away, they can help us understand 'the centre' in terms of the shift towards neoliberalism, local politics or the most personal significations and experiences. Or even better, the conjunction of all of them in complex and contradictory trajectories and characters: fearless and violent, yet protective and caring.

Abarca, Humberto, and Mauricio Sepúlveda. 2005. "Barras Bravas, Pasión Guerrera. Territorio, Masculinidad y Violencia en el Fútbol Chileno." In Jóvenes sin Tregua. Culturas y Políticas de la Violencia. Edited by Francisco Ferrándiz, and Carles Feixa, 145-170. Barcelona: Anthropos.

Adler Hellman, Judith. 2009. "Estudio de los Nuevos Movimientos Sociales en América Latina y la Cuestión de la Autonomía." AméRica Latina Hoy 3. Accessed June 21, 2017. URL: http://revistas.usal.es/index.php/1130-2887/ article/view/2152

Bourgois, Phillippe. 1995. In Search of Respect. Selling Crack in El Barrio. Cambridge: Cambridge University Press.

Butler, Judith. 2009. Frames of War. When is Life Grievable? London, New York: Verso.

Camarena Ocampo, Mario. 2000. "Fábricas y Región: el Sistema Industrial de la Delegación Álvaro Obregón.” In Territorio de Contradicciones: Delegación Álvaro Obregón. Edited by M. Carmen Tostado Gutiérrez, 79-97. México D.F: Gobierno del Distrito Federal, Delegación Política Álvaro Obregón.

Cohen, Albert. 1965. "The sociology of the deviant act: anomie theory and beyond." American Sociological Review. 3/1:5-14.

Gonnell, Raewyn. 2003. Masculinidades. México: PUEG, UNAM.

Gruz, Fermín, and Gustavo Garza. 2014. "Configuración microespacial de la industria en la Ciudad de México a inicios del siglo XXI." Estudios Demográficos y Urbanos 29-1: 9-52.

Davis, Diane E. 1994. Urban Leviathan: Mexico City in the Twentieth Century. Philadelphia: Temple University Press.

Deleuze, Gilles. 2014. El poder. Curso sobre Foucault. Tomo II. Buenos Aires: Editorial Cactus. 
Deleuze, Gilles. 2001. Spinoza: Filosofía Práctica. Barcelona: Fábula Tusquets Editores.

Gillingham, Paul, and Benjamin T. Smith. 2014. "The Paradoxes of Revolution." In Dictablanda: Politics, Work, and Culture in Mexico. Edited by Paul Gillingham and Benjamin T. Smith, 1-43. Durham and London: University Press.

Gutmann, Matthew C. 2000. Ser Hombre de Verdad en la Ciudad de México: ni Macho ni Mandilón. México: Colegio de México, Centro Interdisciplinario de Estudios de la Mujer, Programa Salud Reproductiva y Sociedad.

Harvey, David. 2005. Brief History of Neoliberalism. Oxford: Oxford University.

Knight, Alan, and Wil G. Pansters. 2005. Caciquismo in Twentieth-century Mexico. Michigan: Institute for the Study of the Americas.

Kuldova, Tereza. 2017. 'Guarded Luxotopias and Expulsions in New Delhi: Aesthetics and Ideology of Outer and Inner Spaces of an Urban Utopia', In: Kuldova, T. and Varghese, M. (eds.) Urban Utopias: Excess and Expulsion in Neoliberal South Asia, New York: Palgrave Macmillan.

Laszczkowski, Mateusz, and Madeleine Reeves. 2015. "Affective States Entanglements, Suspensions, Suspicions." Social Analysis 59-4:1-14.

Márquez López, Lisett, and Emilio Pradilla Cobos. 2008. "Desindustrialización, Terciarización y Estructura Metropolitana: un Debate Conceptual Necesario.” Cuadernos del CENDES. 25-69:21-45.

Ortiz Madariaga, Laura Eugenia. 2015. "Temporalidades y Espacios en las Mujeres de Santa Fe en el DF. Identidad y Sentido de Pertenencia." PhD diss., Universidad Autónoma Metropolitana Unidad Iztapalapa.

Perea Restrepo, Carlos Mario. 2007. Con el Diablo Adentro. Pandillas, Tiempo Paralelo y Poder. México: Siglo XXI.

Pfeiffer, James, Keneth Gimbel-Sherr, and Orvalo Joaquim Augusto. 2007. "The Holy Spirit in the Household: Pentecostalism, Gender, and Neoliberalism in Mozambique." American Anthropologist, 109-4: 688-700.

Rojas Quincosa, José Roberto. 2015. "Organización y Movilización en Belén de las Flores." In Historia, Conflicto e Identidad en un Lugar al Poniente de la Ciudad de México, Siglos XVI a XXI. Coordinated by Mario Barbosa, 109-140. México: UAM, Unidad Cuajimalpa.

Shoshan, Nitzan. 2008. "Placing the Extremes: Cityscape, Ethnic 'Others,' and Young Right Extremists in East Berlin.” Journal of Contemporary European Studies, 16-3: 377-391.

Spinoza, Baruch. 1977. Ética demostrada según el orden geométrico. Buenos Aires: Fondo de Cultura Económica.

Wolseth, Jon. 2011. Jesus and the Gang. Youth Violence and Christianity in Urban Honduras. Arizona: The University of Arizona Press.

Yáñez Reyes, Sergio. 2003. Industria y Pobreza Urbana en la Ciudad de México. Antropología Social de los Pobres de Álvaro Obregón. México: Editorial Porrúa.

Adina Radosh Sverdlin holds a Bachelor's degree in Industrial Design and Master's degree in Social Anthropology by the Universidad Iberoamericana in Mexico City. She conducted her thesis research (2015-2016) in neighbourhoods on the West of Mexico 
City, with members of youth gangs from the 70s and 80s. She worked as an external evaluator of a community program for the strengthening of community promoters (2015-2016). Also, she collaborated in a research- action project to prevent child obesity in urban and marginalized contexts in Mexico City (2013-2015) with the Universidad Iberoamericana. She has facilitated workshops, lectures and trainings related to food, society and culture. She conducted a brief research on clay workers and their surroundings in Santa María Atzompa, Oaxaca (2014). 